\title{
Testis tumor associated to microlithiasis
}

\author{
Tumor de testículo associado à microlitíase \\ Tumor de testículo asociado a la microlitíasis
}

Lisieux Eyer de Jesus ${ }^{1}$, Felipe Maciel², Andrea Lima C. Monnerat ${ }^{3}$, Marcia Antunes Fernandes ${ }^{3}$, Samuel Dekermache 4

\section{ABSTRACT}

Objective: To discuss the relationship between testicular microlithiasis and testis tumors in children and to consider the chances of testis preserving surgery in specific cases.

Case description: Pre-adolescent presenting testicular microlithiasis and a larger left testis, corresponding to a cystic testicular tumor. The tumor was excised, with ipsilateral testis preservation. Histology diagnosed a testis dermoid tumor.

Comments: The relationship between testis tumors and testicular microlithiasis is ill defined in children. Pediatric urologists need to develop specific follow-up protocols for pre-pubertal children.

Key-words: testicular tumor; testicular microlithiasis; Pediatrics; testicular dermoid.

\section{RESUMO}

Objetivo: Discutir as implicações da microlitíase testicular na criança com relação ao risco oncológico envolvido e a possibilidade de cirurgia de preservação testicular em casos escolhidos.

Descrição do caso: Pré-adolescente apresentava microlitíase testicular e aumento do testículo esquerdo, correspondendo a tumor testicular cístico. Ressecou-se o tumor, com preservação do testículo. O diagnóstico histológico foi de tumor dermoide testicular.

Comentários: A relação entre tumores de testículo e microlitíase testicular é mal definida em crianças e há a necessidade de desenvolver protocolos de seguimento específicos para essa faixa etária.

Palavras-chave: tumor de testículo; microlitíase testicular; pediatria; tumor dermoide de testículo.

\section{RESUMEN}

Objetivo: Discutir las implicaciones de la microlitíasis testicular en el niño con relación al riesgo oncológico implicado y la posibilidad de cirugía de preservación testicular en casos elegidos.

Descripción del caso: Pre-adolescente presentando aumento microlitíasis testicular y aumento del testículo izquierdo, con lesión tumoral quística. La lesión fue resecada, con preservación del testículo y diagnóstico histológico de tumor dermatoide testicular.

Comentarios: La relación entre tumores de testículo y microlitíasis testicular es mal definida en niños y hay la necesidad de desarrollar protocolos de seguimiento específicos para esa franja de edad.

Palabras clave: Tumor de testículo; microlitíasis testicular; Pediatría; tumor dermoide de testículo.

\section{Introduction}

Pediatric testicular tumors (TT) are rare (0.5-2/100000). Before puberty benign dermoids and teratomas predominate. Yolk sac tumor (YST) represents most malignancies.
Instituição: Departamento de Cirurgia Pediátrica e Urologia e Departamento de Patologia Clínica do Hospital Universitário Antonio Pedro da Universidade Federal Fluminense (UFF) e Departamento de Cirurgia Pediátrica e Urologia do Hospital Federal dos Servidores do Estado, Rio de Janeiro, RJ, Brasil

${ }^{1}$ Hospital Universitário Antonio Pedro da UFF e Hospital Federal dos Servidores do Estado, Rio de Janeiro, RJ, Brasil

${ }^{2}$ Hospital Universitário Antonio Pedro da UFF, Rio de Janeiro, RJ, Brasil

${ }^{3} \mathrm{UFF}$, Rio de Janeiro, RJ, Brasil

${ }^{4}$ Hospital Federal dos Servidores do Estado, Rio de Janeiro, RJ, Brasil

\author{
Endereço para correspondência: \\ Lisieux Eyer de Jesus \\ Rua Presidente Domiciano, 52, apto. 801 \\ CEP 24210-270 - Niterói/RJ \\ E-mail: lisieux@uol.com.br \\ Conflito de interesse: nada a declarar \\ Recebido em: 17/03/2013 \\ Aprovado em: 24/05/2013
}


Testicular microlithiasis (TM) is not uncommon in children and raise concerns about TT and infertility risks, but the evidence for that is debatable, as most data come from adults investigated for infertility and/or testicular dysgenesis syndrome (TDS). The incidence of testicular cancer in adults presenting TM has been estimated as $10 \%$ in a prospective cohort study $^{(1)}$.

We present herein a case testis-preserving surgery to treat a benign TT in a boy attained by diffuse bilateral (DB) TM.

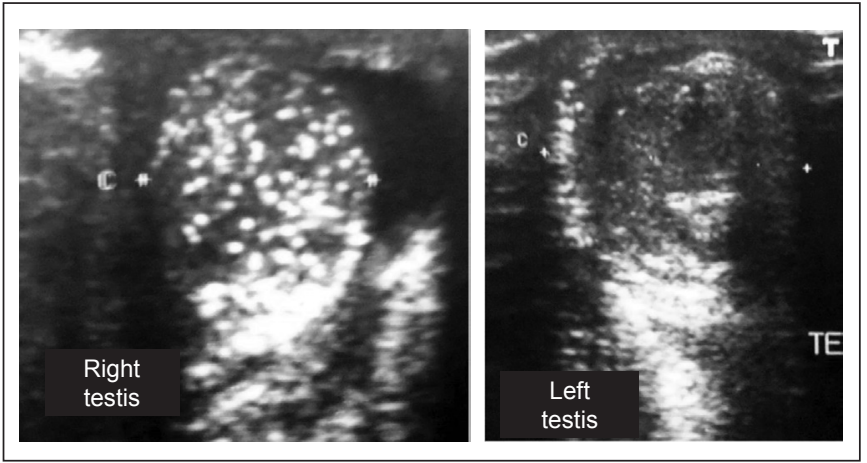

Figure 1 - Ultrasonography aspect of the testes

\section{Case description}

An 11 years old obese Tanner 1 boy was referred for follow up of TM. The mother noticed that the child's left testis was bigger than the right one from toddlerhood.

The boy showed a normal for age stretched length buried penis. Both testes were topical, right testis was normal for age. The left testis was clearly increased, with a hard painless mass attaining the upper pole. Abdominal and inguinal examinations were normal.

An US dated 18 months before his presentation reported DB TM and an augmented left testis, presenting a heterogeneous $21 \times 21 \times 18 \mathrm{~mm}$ upper pole nodule with posterior acoustic shadowing and peripheral vessels. Right and left testes measured, respectively, $25 \times 17 \times 15 \mathrm{~mm}\left(3.3 \mathrm{~cm}^{3}\right)$ and $36 \times 25 \times 23 \mathrm{~mm}\left(10.8 \mathrm{~cm}^{3}\right)$. These findings were confirmed by two other US ( 6 months before and at his presentation) (figure 1). The tumor did not grow during this extensive period of observation. Abdominal US, inguinal US and thoracic radiographs were normal. $\alpha$ fetoprotein $(\alpha \mathrm{FP})$, human chorionic gonadotrophin ( $\beta \mathrm{HCG}$ ) and lactate di-hydrogenase $(\mathrm{LDH})$ blood levels were normal.
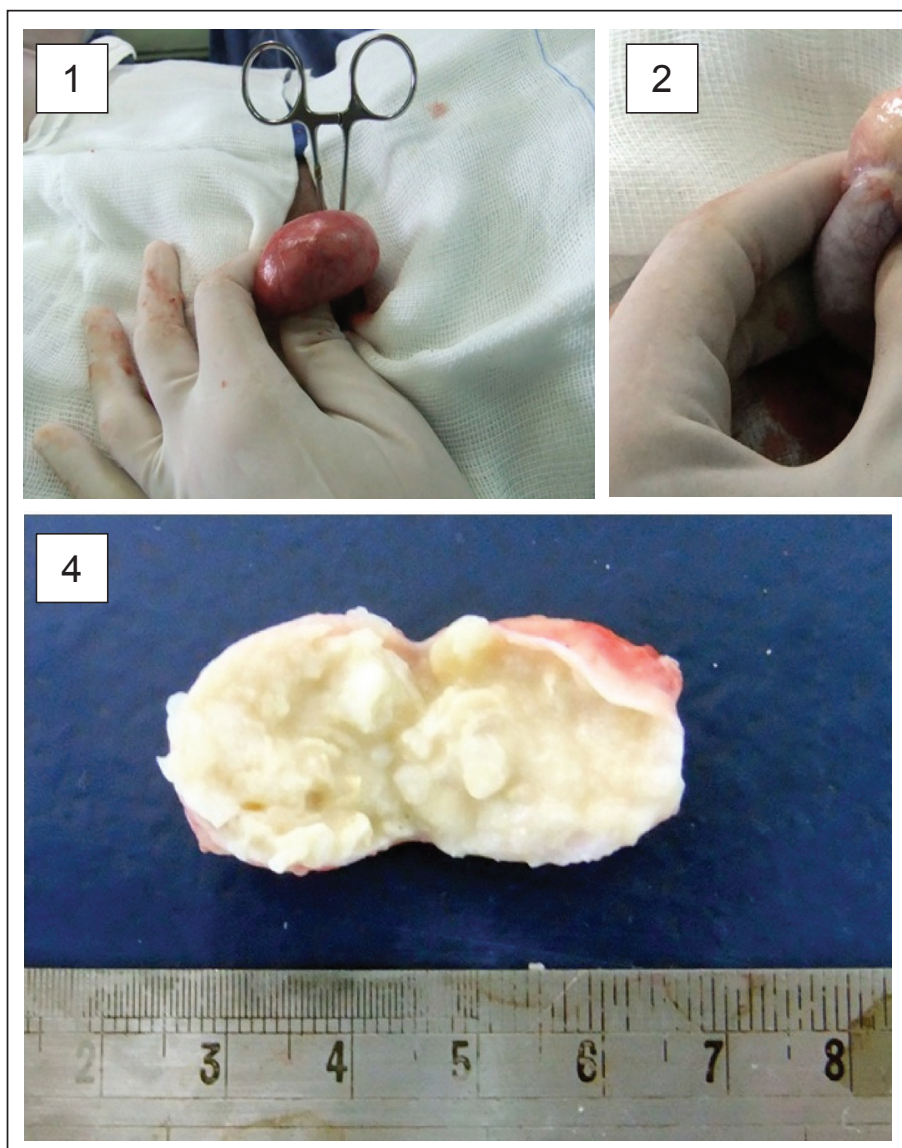
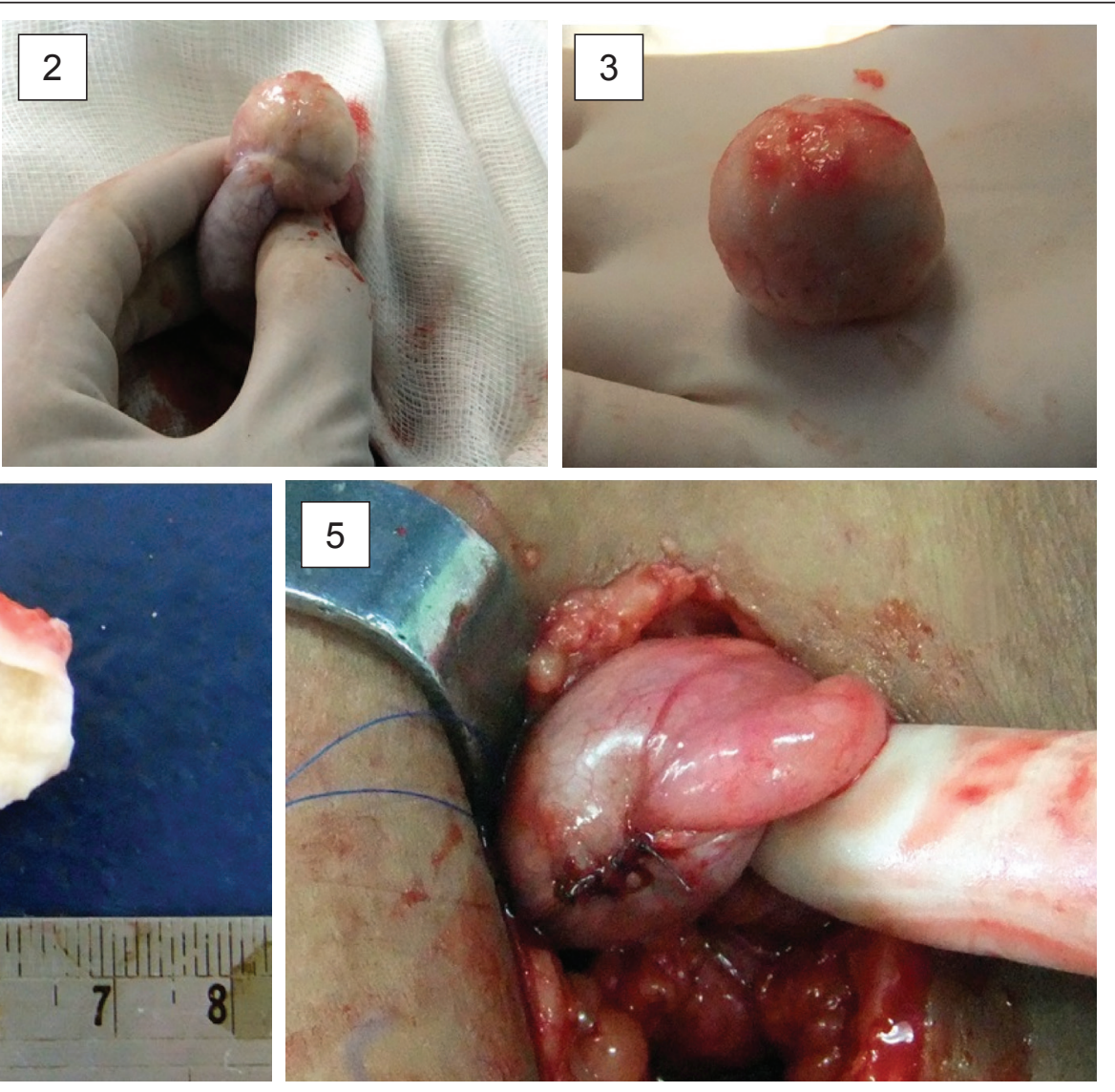

Figure 2 - Testis exposed; (2) Tumor exposed; (3 and 4) Macroscopic aspect of the tumor; (5) Testis reconstructed 
Considering the high probability for a benign tumor we opted to defer abdominal CT and planned a partial left orchiectomy/excisional biopsy with frozen section. The cord was exposed and atraumatically clamped, with a left inguinal excision. No local hypothermia was used. The testis was exposed. A longitudinal anterior incision throughout the adventitia and parenchyma was done, to expose the tumor, which located deep into the upper pole. An encapsulated $20 \times 18 \times 21 \mathrm{~mm}$ round nodule was easily dissected out and sent to the pathologist. Frozen section diagnosed a dermoid tumor, confirmed later on permanent sections. After histological diagnosis the cord was released, the testis was reconstructed and fixed to the left hemiscrotum (figure 2). Total cord clamping time was $35 \mathrm{~min}$.

The patient was released home 12 hours after surgery. There were no post-operative complications. Routine biannual US follow up to address TM and to monitor testes growth was planned.

\section{Discussion}

TM (defined as $\geq 5$ testicular calcifications $\leq 3 \mathrm{~mm}$ ) has become relatively common after the wide usage of US. It's etiology is unknown. Differing theories attribute it to genetic factors, TDS, Sertoli cell dysfunction and/or germ cell degeneration.

The significance of TM in children is unclear, since most research in children involves non-uniform populations (pre and post-pubertal children, different associated diseases). The TM is frequently associated to genetic syndromes (especially
Down(2), Klinefelter(3) and McCune-Albright(4), congenital adrenal hyperplasia(5-6)) and testicular diseases (cryptorchidism, varicocele, testis torsion), which have been associated to infertility and malignancies per se. Most data about TM risks derive from adults being investigated for infertility and/or TDS. Finaly, long-term TM follow-up data in children are unavailable.

Among asymptomatic pre-pubertal children, $4.2 \%$ present TM, mostly DB. A cohort study in 670 normal boys showed a growing incidence from $1.9 \%$ in $<5$ years old to $5.1 \%$ in $5-11$ years old to $5.7 \%$ in $\geq 12$ years old ${ }^{(7)}$. As the reported incidence in adults is $5.6 \%{ }^{(8)}$, this suggests that TM in children is acquired and progresses during school years, becoming stable afterwards.

The proportion of benign masses (mainly teratomas and dermoid cysts) among pre-pubertal TT is significant (38 to $80 \%)^{(9-12)}$. The typical malignant variants are YST, almost always presenting high blood levels of $\alpha F P$. This leaded Pediatric Urologists to advocate testis sparing surgery for prepubertal patients showing normal levels of $\alpha$ FP. Frozen sections are needed to confirm benignity and normal margins in case of teratomas.

The diagnosis of a malignant TT in children during follow up for TM has been reported only 4 times (Table 1$)^{(13-15)}$. Some other patients had synchronic DB TM and TT (2 years old, YST ${ }^{(16)} ; 16$ years old, retroperitoneal YST, no primary detected $^{(17)} ; 17$ years old mixed GCT $\left.{ }^{(18)}\right)$. Another group reported on an 18 years old Klinefelter syndrome patient with a mediastinal malignant teratoma and DB TM. No

Table 1 - Malignant tumors diagnosed during follow up for testicular microlithiasis in children ( $\leq 8$ years old o patients)

\begin{tabular}{|c|c|c|c|c|c|c|c|}
\hline Author & $\begin{array}{c}\text { Age at } \\
\text { diagnosis of TM }\end{array}$ & Follow up & MT & $\begin{array}{c}\text { Age at } \\
\text { tumor } \\
\text { diagnosis }\end{array}$ & $\begin{array}{c}\text { Tumor } \\
\text { characteristics }\end{array}$ & $\begin{array}{c}\text { Tumor } \\
\text { markers }\end{array}$ & Histology \\
\hline $\begin{array}{l}\text { McEniff et a/(13), } \\
1994\end{array}$ & 13 years & Annual US & DB & 17 years & $\begin{array}{l}\text { Solid nodule, } \\
21 \times 4 \times 6 \mathrm{~mm}\end{array}$ & $\begin{array}{c}\uparrow \alpha \mathrm{FP} \\
\uparrow \beta \mathrm{HCG}\end{array}$ & YST \\
\hline $\begin{array}{l}\text { Slaughenhoupt } \\
\text { et } a^{(14)}, 2009\end{array}$ & 11 years & Biannual US & DB & 16 years & $\begin{array}{l}\text { Hyperechoic, } \\
\text { heterogeneous } \\
10 \mathrm{~mm} \text { nodule }\end{array}$ & $\begin{array}{l}\text { Normal } \\
\alpha \mathrm{FP} \\
\uparrow \beta \mathrm{HCG}\end{array}$ & $\begin{array}{c}95 \% \text { Embryonal } \\
\text { cell carcinoma } \\
5 \% \mathrm{YST}^{*}\end{array}$ \\
\hline $\begin{array}{l}\text { Arrigo et } a{ }^{(15)} \\
2006\end{array}$ & 6 years & None & $\mathrm{DB}$ & 9 years & - & - & GCT \\
\hline $\begin{array}{l}\text { Vachon et a/(2), } \\
2006\end{array}$ & 16 years & $\begin{array}{l}\text { US, } \\
\text { periodicity } \\
\text { unknown }\end{array}$ & $\mathrm{DB}$ & 20 years & $\begin{array}{l}\text { Hypoechoic } \\
\text { nodule }\end{array}$ & $\begin{array}{c}\text { Normal } \\
\alpha \mathrm{FP} \text { and } \\
\beta \mathrm{HCG}\end{array}$ & $\begin{array}{l}\text { Leydig cell } \\
\text { tumor }^{* *}\end{array}$ \\
\hline
\end{tabular}

${ }^{*}$ Pulmonary metastases; ${ }^{* \star}$ Bilateral cryptorchidism and previous bilateral orchidopexy; MT: testicular microlithiasis; DB: difuse bilateral; $\alpha F P$ : alfa fetoproteína; YST: yolk sac tumor; US: ultrasound; GCT: germ cell tumor 
primary TT was found and the association may be purely coincidental $^{(3)}$. Leeden et al describe 3 other cases of DB TM with solid TT: one metastatic choriocarcinoma in a 13 years old and 2 Sertoli cell tumors (SCT) in brothers with Peutz-Jeghers syndrome ${ }^{(18)}$. Even if we include doubtful cases (2 SCT, frequently benign, and 2 cases where no testicular primary has been found) and add a non-reported embryonal cell carcinoma in a 16 years old Down syndrome boy ${ }^{(2)}$, we could only find 12 reported cases of malignant TT. This certainly makes the association between TM and testicular malignancies doubtful, but one has to consider lost registers due to publication bias against case reports and short follow ups in TM Pediatric series. Coelho et al described a third case of (benign) SCT in a 11 years old boy with $\mathrm{DB} \mathrm{TM}^{(20)}$. It seems reasonable to speculate about an association between SCT and TM, considering the rarity of this tumor (2.3\% of $\left.\mathrm{TT}^{(21-22)}\right)$.

Benign TT in TM patients are extremely rare, but Bach $e t a l$, in a paper dealing with adults, describe 2 and 5 benign masses in $48 \mathrm{TM}$ and 480 testes without TM, respectively, suggesting that benign tumors tend to be more frequent in TM cases $(p=0.076)^{(23)}$. Deganello et al reported a presumed benign teratoma associated with TM that is being followed up clinically ${ }^{(22)}$. Another case of DB

\section{References}

1. Middleton WD, Teefey SA, Santillan CS. Testicular microlithiasis: prospective analysis of prevalence and associated tumor. Radiology 2002;224:425-8.

2. Vachon L, Fareau GE, Wilson MG, Chan LS. Testicular microlithiasis in patients with Down syndrome. J Pediatr 2006;149:233-6.

3. Aizenstein RI, Hibbeln JF, Sagireddy B, Wilbur AC, O'Neil HK. Klinefelter's syndrome associated with testicular microlithiasis and mediastinal germ-cell neoplasm. J Clin Ultrasound 1997;25:508-10.

4. Savas Erdeve S, Balta H, Balta Z, Dallar Y. Testicular microlithiasis and McCune-Albright syndrome. J Pediatr 2006;148:422-3.

5. Çakir ED, Mutlu FS, Eren E, Paşa AO, Saglam H, Tarim O. Testicular adrenal rest tumors in patients with congenital adrenal hyperplasia. J Clin Res Pediatr Endocrinol 2012;4:94-100.

6. Poyrazoglu S, Saka N, Agayev A, Yekeler E. Prevalence of testicular microlithiasis in males with congenital adrenal hyperplasia and its association with testicular adrenal rest tumors. Horm Res Paediatr 2010;73:443-8.

7. Goede J, Hack WW, van der Voort-Doedens LM, Sijstermans K, Pierik FH. Prevalence of testicular microlithiasis is asymptomatic males 0 to 19 years old. J Urol 2009;182:1516-20.

8. Tan $\mathrm{MH}$, Eng C. Testicular microlithiasis: recent advances in understanding and management. Nat Rev Urol 2011;8:153-63.

9. Ross JH, Rybicki L, Kay R. Clinical behavior and a contemporary management algorithm for prepubertal testis tumors: a summary of the prepubertal testis tumor registry. J Urol 2002;168:1675-8.

10. Metcalfe PD, Farivar-Mohseni H, Farhat W, McLorie G, Khoury A, Bägli DJ. Pediatric testicular tumors: contemporary incidence and efficacy of testicular preserving surgery. J Urol 2003;170:2412-5.
TM and benign teratoma in a 4 years old was added by Horowitz et al ${ }^{(24)}$. Those cases, added by ours, make a total of 3 cases of benign masses in TM cases.

Follow up for TM is controversial, varying between US only after a significant finding (either in clinical evaluation or patient self-palpation) or by-protocol annual or biannual US. There is no consensus about different protocols in children versus adults or asymptomatic cases versus MT associated to other testicular or systemic problems. Involution of prepubertal TM has been reported ${ }^{(25)}$.

While the association between TM and testicular malignancies is at best arguable, in at least one TM patient ${ }^{(17)}$ a metastatic TT developed 6 months after a normal US. Considering the low morbidity and costs, it seems prudent to counsel periodic US, despite informing the family and the patient that TT risk is low. We suggest to follow up Pediatric TM cases with biannual US and to offer fertility testing after puberty, at their request.

As a conclusion, TT associated to TM are rare. Benign TT should be treated with testis-preserving surgery. The risk of malignant TT in pre-pubertal cases of TM is ill-defined. Follow up protocols for TM are debatable, but biannual US seem prudent.

11. Taskinen S, Fagerholm R, Aronniemi J, Rintala R, Taskinen M. Testicular tumors in children and adolescents. J Pediatr Urol 2008;4:134-7.

12. Bujons A, Sfulcini JC, Pascual M, Feu OA, Garat JM, Villavicencio $H$. Prepubertal testicular tumors and efficacy of testicular preserving surgery. BJU Int 2010;107:1812-6.

13. McEniff N, Doherty F, Katz J, Schrager CA, Klauber G. Yolk sac tumor of the testis discovered on a routine annual sonogram in a boy with testicular microlithiasis. AJR Am J Roentgenol 1995;164:971-2.

14. Slaughenhoupt B, Kadlec A, Schrepferman C. Testicular microlithiasis preceding metastatic mixed cell tumor - first pediatric report and recommended management of testicular microlithiasis in the pediatric population. Urology 2009;73:1029-31.

15. Arrigo T, Messina MF, Valenzise M, Rosano M, Alaggio R, Cecchetto G et al. Testicular microlithiasis heralding mixed germ cell tumor of the testis in a boy. J Endocrinol Invest 2006;29:82-5.

16. Drut R. Yolk sac tumor and testicular microlithiasis. Pediatr Pathol Mol Med 2003;22:343-7.

17. Meyer MA, Gilbertson-Dahdal DL. Retroperitoneal extragonadal endodermal sinus tumor with bilateral diffuse classic testicular microlithiasis. J Ultrasound Med 2010;29:1843-7.

18. Pourbagher MA, Kilinc F, Guvel S, PourbagerA, Egilmez T, Ozkardes H. Followup of testicular microlithiasis for subsequent testicular cancer development. Urol Int 2005;74:108-12.

19. Leenen AS, Riebel TW. Testicular microlithiasis in children: sonographic features and clinical implications. Pediatr Radiol 2002;32:575-9. 
20. Coelho R, Brito MJ, Casella P, Bragança G, Machado MC. Microlithiasis and testicular tumor. Acta Med Port 2005;18:485-7.

21. Gómez-García I, Romero Molina M, López-García Moreno A, Buendía González E, Rubio-Hidalgo E, Bolufer $\mathrm{E}$ et al. Sertoli cell tumor, a rare testicular tumor, our experience and review of the literature. Arch Esp Urol 2010;63:392-5.

22. Deganello A, Svasti-Salee D, Allen P, Clarke JL, Sellars ME, Sidhu PS. Scrotal calcification in a symptomatic paediatric population: prevalence, location, and appearance in a cohort of 516 patients. Clin Radiol 2012;67:862-7.
23. Bach AM, Hann LE, Hardar O, Shi W, Yoo HH, Giess CS et al. Testicular microlithiasis: what is its association with testicular cancer? Radiology 2001;220:70-5.

24. Horowitz MB, Abiri MM. US case of the day. Benign cytic teratoma and testicular microlithiasis. Radiographics 1997;17:793-6.

25. Chiang LW, Yap TL, Asiri MM, Phaik Ong CC, Low Y, Jacobsen AS. Implications of incidental finding of testicular microlithiasis in paediatric patients. J Pediatr Urol 2012;8:162-5. 